\title{
Polityka i konstytucja Refleksje nad prawem do prywatności w kontekście orzecznictwa Sądu Najwyższego Stanów Zjednoczonych
}

DOI: $10.35757 /$ CIV.2007.10.04

Demoliberalny ustrój polityczny nakłada na rządzących konieczność nieustannego poszukiwania - jak to określa Stephen Macedo w Cnotach liberalnych - „publicznego uzasadnienia” dla decyzji władczych ${ }^{1}$. Liberalny konstytucjonalizm domaga się potwierdzenia rozumności działań zbiorowych wpływających na jednostkę, na jej indywidualne wybory. Podjęciu decyzji władczej powinna każdorazowo towarzyszyć argumentacja potwierdzająca, że stanowione $\mathrm{i}$ wprowadzane $\mathrm{w}$ życie prawo jest zgodne $z$ interesem publicznym (w Stanach Zjednoczonych interes ten określa się mianem compelling state interest - żywotny interes państwa), którego głównym przedmiotem jest zabezpieczenie wolności i praw

Rafał Prostak - doktor, politolog, amerykanista. Pracuje w Katedrze Stosunków Międzynarodowych Wyższej Szkoły Europejskiej im. ks. Józefa Tischnera w Krakowie.

1 S. Macedo: Cnoty liberalne, przekład G. Łuczkiewicz, Ośrodek Myśli Politycznej, Społeczny Instytut Wydawniczy Znak, Kraków 1995. 
jednostki, jej nietykalności i indywidualnego bezpieczeństwa. Wolności i prawa innych ludzi, porządek i bezpieczeństwo publiczne, zdrowie i moralność publiczna, a także stan środowiska naturalnego sa właściwymi motywami ograniczeń swobody działania jednostki, lecz tylko wtedy, gdy nakładający ograniczenia jest zdolny wykazać: (1) celowość (przydatność) ograniczeń; (2) konieczność ich wprowadzenia $\mathrm{w}$ celu ochrony interesu publicznego; oraz że (3) ograniczenia nałożone na jednostkę pozostają we właściwej proporcji do wartości efektu (pożądanego dobra), do którego dąży podmiot ograniczajacy. „Rządy prawa” zyskują legitymację nie na mocy argumentu siły, ale na mocy siły argumentów. Rozumność prawa jest tu sprzęgnięta $z$ legalnością. Gotowość do formułowania „publicznego uzasadnienia” jest dla Macedo przejawem cnoty rządzacych, a konsekwentne domaganie się owego uzasadnienia stanowi wcielenie cnót rządzonych ${ }^{2}$. Powszechność tych postaw jest miara doskonałości liberalnej wspólnoty politycznej.

Test rozumności decyzji władczych powinien być przeprowadzony w czasie trwania całego procesu ich podejmowania, przede wszystkim zaś na etapie implementacji. Dlatego też $\mathrm{w}$ systemie politycznym demoliberalnego państwa brakuje przestrzeni wolnej od konieczności potwierdzania rozumności decyzji władczej. Niemniej, najważniejszym forum weryfikacji pozostaje sala posiedzeń sądu konstytucyjnego. W Stanach Zjednoczonych sądem majacym zdolność ostatecznej oceny konstytucyjności decyzji podejmowanych przez władze państwowa (stanowa i federalna), w tym jej rozumności, jest federalny Sąd Najwyższy, dziewięcioosobowe kolegium, nominowane przez prezydenta za rada i zgoda Senatu, w którym decyzje zapadają większościa głosów. Jest to prerogatywa, którą określa się mianem kontroli sądowej (judicial review). Macedo zauważa:

Ta aspiracja do publicznej rozumności pomaga wyjaśnić i usprawiedliwić nasze przywiązanie do rządów prawa i kontroli sądowej: temu samemu prawu podlegaja na równi obywatele i urzędnicy publiczni,

Ibidem, s. 340-341. 
a jednostkom wolno zakwestionować interpretację tego prawa podana przez wybieralnych urzędników i zmusić ich do jej ochrony przed sądem wyłączonym spod presji politycznej ${ }^{3}$.

Przytoczony wyżej opis charakteru rządów prawa i kontroli sądowej obejmuje istotne założenie wstępne: sąd pozostaje „wyłączony spod presji politycznej”. Supozycja ta stanowi źródło niezwykłej wagi problemu przy próbie jej realizacji w warunkach amerykańskich. Oto władza sądownicza, oceniając rozumność decyzji władczych legislatywy i egzekutywy, ma być wolna od nacisku politycznego. Tymczasem, mając zdolność stanowienia prawa, nie tylko dokonuje konstytucyjnej weryfikacji legalności działań pozostałych dwóch władz, ale także skutecznie uczestniczy w określaniu warunków ich aktywności. Władza sądownicza nie jest więc jedynie politycznym arbitrem, lecz jest dodatkowo twórca polityki. Uwolniona od nacisku politycznego, sama jednocześnie jest zdolna ten nacisk wywierać. W praktyce - co potwierdza historia amerykańskiego konstytucjonalizmu - „wyłączenie spod presji politycznej” może się okazać niebezpieczne dla kondycji ochrony wolności i praw obywateli. W systemie case law orzeczenia sadowe staja się źródłem prawa (tzw. adjudicative law lub judicial legislation). W takich warunkach do obrony rozumności swych postanowien sa zobowiąane nie tylko legislatywa i egzekutywa (federalna i stanowa). Obowiąek ten spoczywa również na władzy sądowniczej w odniesieniu do jej własnych decyzji władczych - przede wszystkim uprzednio ustanowionych precedensów. Weryfikując rozumność działań innych, sama staje przed koniecznością obrony rozumności własnych decyzji. Przede wszystkim dlatego, że ona również jest normodawca. Nie ogranicza się do rozstrzygania konkretnych sporów, konkretnych przypadków, opierając się na istniejącym prawie, ale podejmuje starania w celu wyznaczenia sposobu rozstrzygania przyszłych sporów. Sąd jest więc zaangażowany w to, co bezwzględnie jest działaniem politycznym - w wybór

3 Ibidem, s. 22. 
między rywalizującymi ze sobą dobrami: wartościami i interesami. Choć podejmuje decyzje w sprawach prywatnych, to ostatecznie jest arbitrem rozstrzygajacym problemy polityki publicznej, przez co nieuchronnie staje się uczestnikiem sporów politycznych.

Już pobieżny przegląd historycznych orzeczeń amerykańskiego Sądu Najwyższego ujawnia niebezpieczna tendencję, która doprowadziła do - jak się to często określa - ustrojowej supremacji sądownictwa (doktryna judicial supremacy). Konstytucyjna prerogatywa kontroli stanowionego prawa została potwierdzona wcześnie, bo już w 1803 roku, w sprawie Marbury v. Madison. Należy jednak pamiętać, że przedmiotem sporu w tej sprawie był ustrój sądownictwa, a konstytucyjna dyskwalifikacja ustawy Kongresu federalnego odbyła się w imię ochrony autonomii sądownictwa oraz trójpodziału władzy. Pierwszą sprawa, w której Sąd Najwyższy zakwestionował wolę legislatury federalnej, a jednocześnie przedmiot sporu nie miał zwiąku $z$ funkcjonowaniem sadownictwa, była sprawa Dred Scott v. Sandford (1857). W orzeczeniu tym, w imię nienaruszalności prawa własności właścicieli niewolników, Sąd Najwyższy podważył kompetencje federalnej legislatywy decydowania o podmiotowości prawnej czarnych mieszkańców Stanów Zjednoczonych. Od połowy XIX wieku przez ponad sto lat Sąd wielokrotnie kwestionował legalność decyzji legislatur stanowych i federalnej, w tym ustaw wzmacniających podmiotowość prawną i polityczna czarnych obywateli, ustaw antytrustowych oraz inicjatyw polityki społecznej epoki New Deal. Za klamrę zamykajaca okres kształtowania się rzekomo konstytucyjnej prerogatywy kontroli sądowej każdej legislacji, bez względu na jej przedmiot - choć żadnych zmian w samym tekście konstytucji w tej materii nie wprowadzono - była sprawa Cooper $v$. Aaron (1958). W orzeczeniu Cooper, autorstwa sędziego Hugo Blacka, znajdziemy interpretacje precedensu Marbury, potwierdzająca (1) absolutna supremację Sądu Najwyższego w decydowaniu o konstytucyjności jakiegokolwiek prawa, a przez to możliwość jego nieodwołalnej derogacji; jak również (2) wyłączne prawo formułowania rozstrzygającej wykładni treści konstytucji. 
Tłem dla tej sprawy była odmowa władz stanowych Arkansas wykonania decyzji Sąu Najwyższego w sprawie Brown v. Board of Education of Topeka (1954). W orzeczeniu Brown Sad podważył konstytucyjność segregacji rasowej w szkolnictwie publicznym w stanie Kansas. W opinii władz stanowych Arkansas była to decyzja o wątpliwej wartości konstytucyjnej; jej wykonanie stanowiłoby pogwałcenie suwerennej woli ludu Arkansas, wyrażonej przez jego przedstawicieli w legislaturze stanowej. Innymi słowy, „publiczne uzasadnienie" decyzji Brown przedstawiało się władzom stanowym w Little Rock jako „nierozumne”. Co warte odnotowania, wprowadzenie segregacji rasowej zostało usankcjonowane przez fedralny Sąd Najwyższy blisko sześćdziesiąt lat wcześniej (sprawa Plessy v. Ferguson [1896]).

Prezentując jednomyślne stanowisko Sądu Najwyższego, sędzia Black miał zauważyć, że:

Ta decyzja [Marbury: uwaga R.P.] określiła podstawową zasadę mówiąca, że federalna władza sadownicza ma pozycję naczelna (supreme) $\mathrm{w}$ wyjaśnianiu norm konstytucyjnych, zaś zasada ta była od tego momentu przestrzegana przez ten Sąd i państwo jako stała i niezastapiona cecha naszego systemu konstytucyjnego. Wynika $z$ tego, że interpretacja XIV Poprawki ogłoszona przez ten Są $w$ sprawie Brown jest nadrzędnym prawem kraju [supreme law of the land], a art. VI konstytucji czyni go wiążącym dla władz stanowych ${ }^{4}$.

W tych kilku słowach Sąd Najwyższy zrównał moc prawną swoich decyzji $z$ normami zawartymi $w$ tekście samej konstytucji. $\mathrm{W}$ ten oto sposób wola Sądu stała się równie wiążąca jak wola ustrojodawcy.

Przejawy sądowej dominacji stanowia poważne wyzwanie dla trwania systemu kontroli i równowagi (checks and balances system) - fundamentu amerykańskiego konstytucjonalizmu. System polityczny zostanie wytrącony $z$ równowagi, gdy wywierający nacisk polityczny sam będzie od niego uwolniony.

4 Wszystkie orzeczenia cytowane w niniejszym tekście można znaleźć w oryginale na stronie www.findlaw.com 
O polityczności działań federalnego Sądu Najwyższego decyduje przede wszystkim to, że swoimi decyzjami kreuje rzeczywistość polityczną, rozszerzając lub zawężając pole decyzyjne pozostałych ośrodków władzy publicznej. Dotyczy to przede wszystkim orzecznictwa w przedmiocie praw obywatelskich (civil rights), gdy swoimi rozstrzygnięciami Sąd Najwyższy określa przyszły zakres konstytucyjnej ochrony tych praw, czasem wbrew preferencjom innych uczestników systemu sprawowania władzy publicznej. Najbardziej interesująca kwestia jest tutaj napięcie - o charakterze ewidentnie politycznym, gdyż dotyczy odpowiedzialności za dobro wspólne - między władzą ustawodawczą i sądowniczą. W demokracji przedstawicielskiej legislatura wypełnia zadanie identyfikacji interesu powszechnego (dobra wspólnego), którego realizacji ma sprzyjać przyjęcie właściwych rozwiązań ustawowych, nakładających na egzekutywę obowiązek podjęcia określonych działań. Treść interesu powszechnego, $z$ założenia, ma być zgodna $z$ opinią większości parlamentarnej w tym przedmiocie, a w państwach, w których stosuje się formułę większościowa, jest w zasadzie odzwierciedleniem woli większości wyborców. Zderzenie woli większości $z$ wolą mniejszości jest zderzeniem wolności (możliwości) realizacji pragnień, preferencji, wartości i interesów większości $z$ analogiczną wolnością mniejszości. Specyfika parlamentarnego sposobu podejmowania decyzji oparta jest na formalnym zrównaniu woli większości $z$ wola powszechna, zwłaszcza jeśli większość parlamentarna jest zdolna przemóc weto zawieszające egzekutywy. Zrównanie, o którym tu mowa, niesie w sobie zagrożenie powstania "tyranii większości", która występuje wtedy, gdy legislacja wdziera się w sferę konstytucyjnie uznana za nienaruszalna wolność indywidualną. Interwencja władzy sądowniczej, która poszukuje w konstytucji wsparcia dla woli mniejszości, stanowi przeszkodę dla pojawienia się „tyranii większości”. W tym stosunkowo prostym rozwiązaniu ustrojowym kryje się jednak kłopotliwy dylemat. Może bowiem na- 
stapić sytuacja odwrotna: oto „tyrania mniejszości” powstrzymuje większość od podjęcia decyzji władczych przyznanych jej konstytucyjnie $^{5}$. Blokada woli większości nastapi naturalnie $\mathrm{w}$ efekcie interwencji sadu konstytucyjnego. Ponieważ decyzja sądu będzie wymagać „publicznego uzasadnienia”, konieczne staje się przywołanie rozstrzygnięć konstytucyjnych.

W literaturze przedmiotu wyróżnia się dwie doktryny orzecznictwa konstytucyjnego Sądu Najwyższego. Sa to judical activism („aktywizm sędziowski”) oraz judicial restraint („sędziowska powściagliwość"). Merriam-Webster's Dictionary of Law definiuje judical activism jako „praktykę władzy sądowniczej stosowana w celu ochrony lub rozszerzenia praw jednostki poprzez decyzje nie będące realizacja ustanowionych wcześniej precedensów, ewentualnie niezależnie od (lub rozbieżnie z) zamiarami legislatora

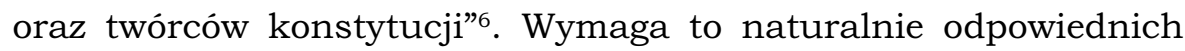
zabiegów interpretacyjnych, które wychodza poza tekst konstytucji oraz poszukuja wsparcia głównie $\mathrm{w}$ wartościach i twierdzeniach moralnych, na których ma być oparty amerykański konstytucjonalizm. Sąd powołuje się więc nie tyle na „literę konstytucji”, ile na jej „ducha”. Natomiast judicial restraint nakazuje sadowi powstrzymanie się przed „kreatywna” interpretacją Konstytucji Stanów Zjednoczonych; zakazuje wychodzić poza wykładnię literalną oraz intencje jej twórców (doktryna original intent). Słownik Merriam-Webster's definiuje judicial restraint jako „powstrzymywanie się władzy sądowniczej od odchodzenia od precedensu i formułowania szerokiej doktryny"7. W praktyce o „aktywizm sędziowski” posądza się najczęściej Sąd Najwyższy, czy też poszczególnych jego członków, gdy $\mathrm{w}$ imię implicite wyrażonych $\mathrm{w}$ konstytucji praw obywatelskich, rzekomo $z$ niej wywiedzionych, podważona zostaje konstytucyjność ustawy, czyli legalność decyzji reprezentantów

\footnotetext{
5 Na paradoks ten zwraca uwagę między innymi uznany amerykański konstytucjonalista Robert H. Bork: Neutral Principles and Some First Amendement Problems, w: J.H. Garvey, T.A. Aleinikoff (red.): Modern Constitutional Theory. A Reader, West Publishing Co., St. Paul 1994, s. 117.

6 Merriam-Webster's Dictionary of Law (1996) (www.dictionary.lp.findlaw.com/dictionary.html). 7 Ibidem.
} 
demos stanowego lub federalnego. „Sędziowską powściagliwość" ma natomiast cechować szacunek wobec „woli większości”.

III

Przedmiotem niniejszego opracowania jest prezentacja wybranych orzeczeń federalnego Sądu Najwyższego w zakresie konstytucyjnych gwarancji prawa do prywatności; prawa, którego ochrona nie została wprost zabezpieczona w Konstytucji Stanów Zjednoczonych. Wybór ten ułatwia uchwycenie napięcia między doktryną sędziowskiego aktywizmu i sędziowskiej powściagliwości, skoro prawo do prywatności cieszy się federalną ochrona prawna jedynie na skutek rozszerzajacej interpretacji konstytucji ${ }^{8}$.

Amerykańska doktryna prawa do prywatności nie ogranicza jego zasięgu do nienaruszalności spokoju domowego i korespondencji (jak zazwyczaj zawężamy prywatność w potocznym rozumieniu), ale obejmuje również: prawo do stosowania środków antykoncepcyjnych; prawo kobiety do aborcji; prawo do realizacji seksualnej osób o odmiennej orientacji seksualnej; prawo do "godnej śmierci”; prawo do ochrony dobrego imienia i wizerunku; zakaz wykorzystywania wizerunku danej osoby bez jej zgody w celu osiagnięcia korzyści oraz swobodę kontaktów $z$ innymi ludźmi w sferze działalności zawodowej, w tym handlowej. Wszystkie te desygnaty prawa do prywatności umieszcza się w amerykańskiej literaturze

\footnotetext{
8 Konstytucyjna ochrona prawa do prywatności jest w Stanach Zjednoczonych wyprowadzana na zasadzie wykładni rozszerzajacej z poprawek Karty Praw (pierwszych dziesięć poprawek do Konstytucji) oraz Poprawki XIV. I tak: $z$ wolności religijnej, gwarantowanej w I Poprawce, wyprowadzono prywatność w wymiarze duchowym (wolność sumienia jako szczególna postać prawa do prywatności); $z$ wolności od obowiazku kwaterowania wojska w czasie pokoju, gwarantowanej w III Poprawce, wyprowadzono prywatność w wymiarze przestrzennym (domostwo); $z$ nietykalności osobistej, gwarantowanej w IV Poprawce, wyprowadzono prawo do prywatności w wymiarze przestrzennym (osoba i jej domostwo, korespondencja); $z$ zakazu przejmowania własności prywatnej bez słusznego odszkodowania, opisanego w V Poprawce, wyprowadzono prawo do prywatności w wymiarze przestrzennym (domostwo); zgodnie z IX Poprawka, konstytucyjna prezentacja praw podmiotowych nie jest zamknięta, więc prywatność również może podlegać ochronie prawnej; z kolei XIV Poprawka umożliwią szeroka interpretację zasady wolności osobistej, zaś prawo do prywatności jest jej przejawem.
} 
przedmiotu pod szyldem, pochodzacej $z$ końca XIX wieku, doktryny prawa do „bycia pozostawionym w spokoju” (to be left alone). Nakaz niewtrącania się w życie jednostki, nałożony na innych, a przede wszystkim na władzę państwową, nie ma wyraźnie zakreślonych granic. Państwo jest zobowiąane do powstrzymywania się od bezprawnej i arbitralnej ingerencji w świat obywatela, przy czym granice świata wolnego od tego rodzaju ingerencji nie sa precyzyjnie ustalone i podlegaja nieustannemu modelowaniu przez władzę sądowniczą. Judith Shklar uznała tę czasowa zmienność granicy prawa do prywatności za cechę charakterystyczną demoliberalnego porządku politycznego:

Dla liberalizmu ważniejsze jest nie to, gdzie linia jest narysowana, lecz to, iż należy ja gdzieś umiejscowić i że pod żadnym pozorem nie można jej ignorować lub o niej zapomnieć. Granice przymusu zaczynają się, chociaż się nie kończa, w miejscu zakazu pogwałcenia sfery prywatności, która początkowo rozumiano $\mathrm{w}$ kategoriach przekonań religijnych, lecz która zmieniała i będzie zmieniać swój zasięg wraz ze zmiana treści przekonań i zmiana sensu prywatności, wskutek postępującej dominacji technologicznego i militarnego charakteru rząów oraz ekonomizacji relacji międzyludzkich. Jest to ruchoma linia, lecz nie można jej usunać, co pozwala liberałom czuć się wolnymi w przyjmowaniu bardzo szerokiego spektrum przekonań filozoficznych i religijnych ${ }^{9}$.

Szczególna nieokreśloność zakresu prawa do prywatności i brak jego umocowania w tekście Konstytucji Stanów Zjednoczonych wzmacnia pozycję władzy sądowniczej jako interpretatora pierwotnej woli ustrojodawcy oraz "ducha” ustawy zasadniczej. Pojawienie się napięcia między aktywizmem i powściagliwością sędziowska $\mathrm{w}$ przedmiocie prawa do prywatności jest nieuchronne.

\section{IV}

Prawo do prywatności pojawiło się w orzecznictwie federalnego Sadu Najwyższego stosunkowo późno, bo dopiero w drugiej poło9 J. Shklar: The Liberalism of Fear, w: N. Rosenblum (red.): Liberalism and the Moral Life, Har-
vard University Press, Cambridge 1989, s. 24-25. 
wie XX wieku, wraz z konstytucyjna ocena prawa do regulowania płodności, w tym do dystrybuowania i stosowania środków antykoncepcyjnych oraz do aborcji z przyczyn innych niż ochrona życia i zdrowia kobiety.

W sprawie Griswold v. Connecticut (1965) przedmiotem sporu były przepisy karne stanu Connnecticut penalizujace propagowanie i stosowanie „nienaturalnej” antykoncepcji, jak również szkolenie w zakresie jej stosowania. Na dwóch pracowników poradni świadomego macierzyństwa władze stanowe nałożyły grzywnę w wysokości 100 dolarów za instruktaż, jakiego udzielili parze małżeńskiej. Sąd Najwyższy, w orzeczeniu przygotowanym przez sędziego Williama O. Douglasa, odniósł się do definicji interesu publicznego przywołanego przez legislaturę stanowa (płodność obywateli), by następnie zakwestionować rozumność przepisu karnego będacego przedmiotem sporu. Zdaniem Sadu przepis ten nakładał ewidentnie nieproporcjonalne ograniczenia na wolność małżonków w stosunku do efektu społecznego, jaki miał powodować. Rozumność decyzji legislatury stanowej została podważona, a odpowiedzialność karna ciążąca na pracownikach poradni świadomego macierzyństwa zdjęta. Interes publiczny miał $\mathrm{w}$ tej sprawie ustąpić prawu do prywatności. Brak wyrażonych explicite konstytucyjnych gwarancji prawa do prywatności nie stanowił dla Sądu przeszkody, gdyż, jak przekonywał sędzia Douglas:

Mamy tu do czynienia $z$ prawem do prywatności starszym niż Karta Praw; starszym nawet niż partie polityczne lub system oświatowy. Małżeństwo to dwoje ludzi, którzy łączą się na dobre i złe, trwają przy sobie pełni nadziei i prowadzą wspólne życie tak dalece intymne, że wręcz święte. Małżeństwo jest związkiem mającym wspierać określony tryb życia, a nie jakieś interesy; związkiem, który ma wspierać harmonijne współżycie, nie zaś programy polityczne; który ma wspierać wzajemną wierność, a nie inicjatywy gospodarcze czy społeczne.

Za sprawą „aktywizmu sędziowskiego” sędziego Douglasa, w federalnym porządku prawnym pojawiło się nowe prawo podmiotowe: prawo do prywatności obejmujące wolność od nieuzasadnionej 
ingerencji państwa w sprawy małżeńskie, we „wspólne życie tak dalece intymne, że wręcz święte”. Prawo do prywatności przyjmuje tu postać praw reprodukcyjnych, wolnych od pokusy instrumentalnego traktowania przez władze ustawodawcza w imię programów politycznych oraz inicjatyw społecznych i gospodarczych.

W obronie prawa legislatury stanowej do określania interesu publicznego i zwiazanych $z$ jego realizacja ograniczeń nakładanych na swobody obywateli wystapił sędzia Potter Stewart, w którego zdaniu przeciwnym czytamy:

Od roku 1879 w kodeksach stanu Connecticut mamy prawo, które zakazuje stosowania antykoncepcji. Wydaje mi się, że jest to nadzwyczaj głupie prawo $[\ldots]$. Lecz nie jesteśmy $\mathrm{w}$ tej sprawie proszeni o odpowiedź na pytanie, czy nie wydaje nam się, że to prawo jest niemadre lub wręcz głupie. Jesteśmy proszeni o podtrzymanie twierdzenia, że gwałci ono Konstytucję Stanów Zjednoczonych. A tego nie mogę zrobić [...]. Istota obowiazku sędziowskiego jest poddanie osobistych poglądów, naszych własnych opinii o tym, jakie prawo jest mądre, a jakie nie. Jeśli, jak mam nadzieję, prawo, które tu przed nami stoi, nie odzwierciedla standardów właściwych ludowi Connecticut, lud ten może w sposób wolny uczynić użytek $z$ praw wynikających IX i X Poprawki, by przekonać swych wybranych przedstawicieli do odwołania tego prawa. Oto jest konstytucyjna droga do usunięcia tego prawa $z$ kodeksów.

W przytoczonej wyżej wypowiedzi pojawia się istotna uwaga. Sędzia Stewart dyskwalifikuje sensowność legislacji stanu Connecticut, co nie przekłada się jednak na gotowość akceptacji stanowiska większości składu orzekającego. Judykacyjne badanie rozumności ogranicza się bowiem, jego zdaniem, jedynie do oceny zgodności $z$ federalna konstytucja przepisu prawa stanowego. Badanie to powinno być wolne od osobistych opinii o wartości intelektualnej przepisu. „Polityczna” ocena rozumności badanej legislacji należy do ludu Connecticut, nie zaś do federalnego Sąu Najwyższego.

Po upływie siedmiu lat od uznania prawa do stosowania środków antykoncepcyjnych przez małżeństwa, Sąd Najwyższy potwierdził analogiczne prawo osób stanu wolnego - sprawa Eisenstadt v. Baird (1972), w której odrzucono „rozumne uzasadnienie” kry- 
minalizacji, w imię moralności publicznej, propagowania antykoncepcji wśród dorosłych osób stanu wolnego. Oskarżony w tej sprawie aktywista ruchu świadomego planowania macierzyństwa, o nazwisku Baird, wręczył niezamężnej kobiecie żel antykoncepcyjny. Raz wprowadzone pojęcie prywatności na salę sądowa, w rozumieniu prawa do regulowania swej płodności, już na niej pozostało. W orzeczeniu Sadu, przygotowanym przez sędziego Williama J. Brennana, czytamy:

Jeśli prawo do prywatności ma jakiekolwiek znaczenie, to jest ono prawem jednostki, stanu wolnego lub nie, do pozostawania wolna od nieuzasadnionych ingerencji państwa $\mathrm{w}$ tak istotnych dla jednostki sprawach jak płodzenie i rodzenie dzieci.

W ten oto sposób prawo do antykoncepcji, jako szczególnej postaci prawa do prywatności, w pełni uniezależniono od instytucji małżeństwa i praw $z$ niej płynących.

Obecność prawa do prywatności w orzecznictwie amerykańskiego Sąu Najwyższego została utrwalona w bodaj najbardziej znanym przykładzie aktywizmu sędziowskiego, jakim jest sprawa Roe v. Wade (1973). Przedmiotem sporu było prawo penalizujace aborcję w stanie Teksas, gdzie od blisko wieku kryminalizowano przerywanie ciąży $z$ przyczyn innych niż ochrona życia kobiety. Ponieważ nie stwierdzono zagrożenia życia kobiety o przybranym nazwisku Roe, odmówiono jej prawa do aborcji.

Są Najwyższy w swojej decyzji uznał ciązę i macierzyństwo za elementy świata, do którego należy również małżeństwo, stosunki rodzinne oraz związane $z$ tym wychowanie i kształcenie dzieci. Jest to sfera prywatna podlegająca szczególnej ochronie prawa. Ingerencja $\mathrm{w}$ sferę prywatna wymaga wykazania zagrożenia dla „żywotnego interesu państwa", który w określonych okolicznościach uzasadnia ograniczenie prawa do prywatności. Sad nie znalazł takiego uzasadnienia $\mathrm{w}$ pierwszym trymestrze ciaży, kiedy to zabieg aborcji jest bezpieczny, a płód nie jest w stanie żyć poza organizmem matki. Dlatego też stwierdził, iż w okresie tym państwo 
nie może ingerować $\mathrm{w}$ decyzję kobiety o utrzymaniu lub przerwaniu ciąży - brak ograniczeń nakładanych na prywatność kobiety. Inaczej rzecz się ma $\mathrm{w}$ drugim i trzecim trymestrze, gdy - w imię bezpieczeństwa kobiety i zdolności płodu do życia poza organizmem matki - państwo może ograniczyć dostępność zabiegu przerywania ciąży. Stanowisko Sąu - które jest wyraźna kontynuacja linii orzecznictwa zapoczątkowanej w sprawie Griswold i kontynuowanej w sprawie Eisenstadt - przedstawił sędzia Harry Blackmun:

Prawo do prywatności, bez względu na to, czy będzie odnalezione w koncepcji wolności osobistej oraz ograniczeniach nakładanych na działania państwa $z$ XIV Poprawki, czy, jak my czujemy [we feel], jest ono, zgodnie $z$ ustaleniami sadu dystryktowego, obecne w zasadzie zachowania praw ludu z IX Poprawki, jest ono wystarczajaco pojemne, by objąć decyzję kobiety o tym, czy chce przerwać swą ciążę.

W argumentacji tej dostrzegamy nie tylko odwołanie do faktów, lecz również do intuicji Sądu (,jak my czujemy”).

Stanowiska Sądu nie podzielił sędzia Byron R. White, który, w imię sędziowskiej powściagliwości, odrzucił argumentację większości opierająca się na rozszerzającej wykładni Konstytucji Stanów Zjednoczonych i uznał, że w sprawie Roe Sąd Najwyższy w bezzasadny sposób pogwałcił wolę mającej demokratyczny mandat legislatury stanu Teksas, ograniczając w ten sposób prawo obywateli tego stanu do stanowienia o sobie:

Nie znajduję niczego w historii Konstytucji, co stanowiłoby wsparcie dla decyzji Sądu Najwyższego. Są zwyczajnie modeluje i ogłasza nowe konstytucyjne prawo ciężarnej matki, nie przedstawiając istotnego powodu dla swego działania; wyposażając to prawo w wystarczająca treść, aby uchylić większość istniejacych regulacji stanowych w kwestii aborcji. W efekcie obywatele i legislatury pięćdziesięciu stanów traca tytuł konstytucyjny do ważenia relacji ważności interesów kontynuowania rozwoju płodu, $z$ jednej strony, i spektrum możliwych konsekwencji dla matki, $z$ drugiej strony. Surowo korzystajac ze swej władzy, Sąd pewnie ma możliwość uczynić to, co zrobił dzisiaj; lecz w mojej opinii to orzeczenie jest improwizacja i ekstrawagancja korzystania $z$ władzy kontroli sądowej, w którą Konstytucja wyposaża ten Sąd. 
Sąd Najwyższy, podejmując swoją decyzję, ograniczył zdolność decyzyjna władz stanowych, przyjmując jako podstawę wydanego orzeczenia swą własna, rozszerzająca interpretację konstytucji, dla której uzasadnieniem była wyłącznie intuicja co do treści, które można rzekomo wywieść z I, III, IV, V, IX i XIV Poprawki.

Prawo do prywatności zostało przywołane również w sprawach, w których przedmiotem sporu była kryminalizacja aktywności seksualnej osób o orientacji homoseksualnej.

W 1986 roku Sąd Najwyższy rozstrzygną sprawę z powództwa Michaela Hardwicka, który został aresztowany wraz ze swoim partnerem za uprawianie seksu oralnego we własnej sypialni, na co obaj wyrazili zgodę (Bowers $v$. Hardwick). Mimo że prokurator ostatecznie odstapił od ścigania, Hardwick wniósł powództwo przeciw władzom stanowym, domagając się zniesienia przepisów stanu Georgia penalizujacych stosunki homoseksualne. Hardwick twierdził, że naruszono jego prawo do prywatności. Nawet jeśli stosunki homoseksualne sa w odbiorze opinii publicznej przestępstwem, to jeśli dochodzi do nich przy obopólnej zgodzie i w zaciszu domowym, maja one charakter przestępstw bez ofiar (victimless crimes) i jako takie nie powinny być ścigane.

Są Najwyższy nie przychylił się do argumentów obrony i uznał, że decyzja władz Georgii była zgodna $z$ konstytucja, gdyż zasada nieingerencji $\mathrm{w}$ życie erotyczne obywateli w zaciszu domowym odnosi się jedynie do par heteroseksualnych. Szanując decyzję legislatury stanowej, Sad oddalił powództwo. Opinię większości przedstawił sędzia Byron White:

Nie chcemy zbyt szeroko traktować naszych uprawnień, odkrywajac nowe prawa podstawowe, zawarte jakoby w klauzuli „właściwego wymiaru sprawiedliwości” [due process of law]. Są Najwyższy jest na najsłabszym gruncie i zbliża się do granic prawa wówczas, gdy ma do czynienia $z$ regułami konstytucyjnymi tworzonymi przez sądownictwo, regułami 
o słabych czy wręcz nierozpoznawalnych związkach $z$ językiem czy intencjami konstytucji. W takich sytuacjach mamy do czynienia $z$ uzurpowaniem sobie przez władzę sądownicza coraz to większych uprawnień do rządzenia krajem bez wyraźnej podstawy konstytucyjnej. [...] Twierdzenie, że prawo do takiego zachowania (sodomia) jest głęboko zakorzenione w tradycji oraz że wpisuje się bezpośrednio w kontekst konstytucyjnej wolności, zakrawa na żart.

Stanowiska Sąu Najwyższego nie podzielił sędzia Harry Blackmun, autor decyzji w sprawie Roe, dla którego prawo do prywatności w sposób oczywisty obejmuje akt miłości homoseksualnej $\mathrm{w}$ zaciszu domowym, na równych prawach $z$ aktem seksualnym par heteroseksualnych. Dlatego też mógł stwierdzić: „Prawo jednostki do utrzymywania intymnych związków we własnym domu leży, moim zdaniem, u sedna konstytucyjnej ochrony prywatności".

Stanowisko Sąu Najwyższego w opisywanym przedmiocie uległo zasadniczej zmianie $\mathrm{w}$ efekcie sprawy Lawrence $v$. Texas (1998). Wnoszącymi skarge byli dwaj mężczyźni, John Lawrence i Tyron Garner, których lokalny szeryf przyłapał w ich domu na uprawianiu sodomii. Następnego dnia sąd skazał ich na grzywnę w wysokości 200 dolarów. Postępowanie odwoławcze zakończyło się sukcesem apelujących. Sąd Najwyższy przełamał swój własny precedens z 1986 roku i dodatkowo przeprosił za tamta decyzję. W opinii większości, przygotowanej przez sędziego Anthony Kennedy'ego, czytamy:

[...] homoseksualiści maja prawo do poszanowania ich życia prywatnego.

[...] Państwo nie może ich poniżać lub kontrolować ich życia poprzez uznawanie ich prywatnych zachowan seksualnych za przestępstwo.

W opozycji znalazł się sędzia Antonin Scalia, który w emocjonalnej reakcji zarzucił Sąowi Najwyższemu zajęcie stanowiska $\mathrm{w}$ sporze politycznym fundamentalnie dzielącym społeczeństwo amerykańskie. W zdaniu przeciwnym czytamy:

Tym orzeczeniem Sąd zajął stronę w wojnie kulturowej i podpisał się pod programem homoseksualnym, który jest obliczony na wyeliminowanie odrazy moralnej, tradycyjnie towarzyszacej zachowaniom homoseksu- 
alnym. Kolejnym tego logicznym krokiem będzie legalizacja małżeństw osób tej samej płci.

Obawy sędziego Scalii na razie się nie potwierdziły, jeśli chodzi o poziom federalny. Na poziomie stanowym, w jednym przypadku, akt ten rzeczywiście się dokonał. W 2003 roku Sąd Najwyższy stanu Massachusetts zalegalizował małżeństwa osób tej samej płci, jednocześnie definiując definicję istoty małżeństwa:

Ponieważ korzyści wynikające wyłącznie $z$ faktu zawarcia małżeństwa sa ogromne, gdyż dotycza każdego aspektu życia i śmierci, prawo do korzystania $z$ nich byłoby ułomne, gdyby nie obejmowało prawa do poślubienia wybranej osoby. [...] To nie płodzenie dzieci, lecz wyłaczność i trwałość związków partnerów stanowia o istocie małżeństwa. Strony nie dąża do podważenia instytucji małżeństwa, lecz do jej stosowania.

Na mocy decyzji stanowego Sadu Najwyższego w Massachusetts, od 17 maja 2004 roku mieszkańcy tego stanu moga wchodzić w prawnie wiążace, jednopłciowe związki małżeńskie. Reakcja legislatur innych stanów była zdecydowana. Obecnie w konstytucjach 27 stanów można znaleźć definicję małżeństwa jako związku jednej kobiety i jednego mężczyzny, a 41 stanów wprowadziło ustawę definiujaca małżeństwo w ten sam sposób (tzw. Defense of Marriage Act - DOMA). Jedynie sześć stanów zrezygnowało $z$ tego rodzaju zabezpieczeń instytucji małżeństwa jako związku dwupłciowego. Od 1996 roku DOMA funkcjonuje również w prawie federalnym ${ }^{10}$, dzięki czemu związki jednopłciowe zawarte w stanie Massachusetts nie powoduja skutków prawnych dla administracji

10 „Przy określeniu znaczenia jakiejkolwiek ustawy przyjętej przez Kongres, jakiegokolwiek prawa, regulacji czy interpretacji wszelkiego biura czy agencji administracji federalnej, termin "małżeństwo" oznacza wyłącznie związek prawny między jednym mężczyzną i jedną kobieta, mężem i żona, zaś termin "małżonek" odnosi się wyłącznie do osoby płci przeciwnej, która jest mężem lub żona". U.S. Code, tytuł 1, rozdział 1, § 7 .

„Żaden stan, terytorium, terytorium zależne czy też plemię indiańskie nie będzie zmuszane do wprowadzenia w życie jakiegokolwiek aktu, zapisu lub postanowienia sadowego innego stanu, w którym uznaje się związek między osobami tej samej płci za równorzędny małżeństwu zgodnie $z$ prawem tego stanu, terytorium, terytorium zależnego czy też plemienia indiańskiego, jak również praw i roszczeń wynikających $z$ takich związków”. Ibidem, tytuł 28 , część 5, rozdział 115, § 1738 c. 
federalnej. Federalny Sąd Najwyższy do dziś nie zajął stanowiska w przedmiocie zgodności DOMA, stanowych i federalnej, $z$ federalną konstytucją.

\section{VI}

Decyzja władcza wymaga „publicznego uzasadnienia”. Zasada ta powinna dotyczyć każdego decydenta, w tym władzy sądowniczej. Jednocześnie $\mathrm{w}$ amerykańskim systemie politycznym kontrola konstytucyjności decyzji władczych formalnie leży w wyłącznej kompetencji sadownictwa. Czy te dwie zasady nie pozostaja ze soba $\mathrm{w}$ kontradykcji? Czy $\mathrm{w}$ demoliberalnym ustroju politycznym jest miejsce dla podmiotu przypisującego sobie prerogatywę (lub jest mu ona przypisywana) wydawania ostatecznych, nieodwołalnych rozstrzygnięć, których treść może zmienić jedynie on sam. Oddajmy raz jeszcze głos Stephenowi Macedo:

W liberalnej wspólnocie interpretatorów nie ma suwerena, któremu przysługiwałby bezwzględny autorytet; żadna instytucja sądownicza, ustawodawcza, wykonawcza czy nawet instytucja demokracji bezpośredniej nie ma ostatecznego słowa w kwestii tego, co jest konstytucyjnie dopuszczalne. Decyzje takie należy podejmować, lecz polityczna dyskusja nigdy nie zostanie zamknięta ${ }^{11}$.

Jeśli do federalnego Sądu Najwyższego należy prawo ostatecznego, rozstrzygającego głosu w ocenie konstytucyjności wszelkich decyzji władczych, to ma on również prawo „zamknięcia dyskusji politycznej”. W takich okolicznościach zasada „rządu ograniczonego”, system „hamulców i równowagi”, a przede wszystkim sama demokracja staja przed poważnym wyzwaniem. Arbiter konstytucyjny, nie poddany w swym postępowaniu realnej kontroli i nie pochodzacy $z$ demokratycznego wyboru, ma być gwarantem porządku demokratycznego, w którym to lud ma stanowić

${ }^{11}$ S. Macedo: Cnoty..., s. 104. 
o sobie. Zgodne stanowisko pięciu nominatów może unieważnić decyzję władcza legislatywy i egzekutywy, stanowej i federalnej, mających demokratyczna legitymacje polityczna. W ten oto sposób „rządy prawa” stają się nieodróżnialne od rząów judykatury. Historia orzecznictwa federalnego Sąu Najwyższego Stanów Zjednoczonych potwierdza, że obawy wypływajacce $z$ tego stanu rzeczy sa zasadne, w tym także w odniesieniu do decyzji Sądu w kwestii zakresu przedmiotowego prawa do prywatności. 